\title{
DNA Microarray Analysis of Human Gene Expression Induced by a Non-lethal Dose of Cadmium
}

\author{
Hirotomo YAMADA ${ }^{1 *}$ and Shinji KOIZUMI ${ }^{2}$
}

\author{
${ }^{1}$ Division of Health Effects Research and \\ ${ }^{2}$ Division of Hazard Assessment, National Institute of Industrial Health, 6-21-1, Nagao, Tama-ku, Kawasaki 214- \\ 8585, Japan
}

Received January 15, 2002 and accepted February 5, 2002

\begin{abstract}
Cadmium (Cd) is a hazardous heavy metal present in working and living environments. Cd affects many cellular functions, but little is known about the mechanisms of its toxicity and cellular defense against it. Recently, advanced gene expression analysis employing DNA microarrays provided us the means to profile the expression of thousands of genes simultaneously. We describe here a study of Cd-induced gene expression profile. Messenger RNA was prepared from HeLa cells exposed to a non-lethal dose of $\mathrm{CdSO}_{4}$, and analyzed by the use of an array consisting of 7,075 human cDNAs. Many stress response genes including those coding for metallothioneins and heat shock proteins were observed to be induced by $\mathrm{Cd}$. The cellular metabolism inclined toward the synthesis of cysteine and glutathione after $\mathbf{C d}$ exposure. Anti-oxidant genes also appeared to be induced to protect cell components and to quench reactive oxygen species. Ubiquitin pathway was activated as well probably to degrade proteins which might not be renatured. These data suggest that human cells mobilize every genomic resource (induction of some genes and repression of others) to overcome cytotoxicity caused by $\mathrm{Cd}$.
\end{abstract}

Key words: DNA microarray, Cadmium, Stress proteins, mRNA, Anti-oxidant

\section{Introduction}

Development of modern chemical industry has made our life convenient and comfortable. But we should not forget the fact that the products of the chemical industry give rise to many symptoms in the people who work in their production. To cite an example, cadmium $(\mathrm{Cd})$ is required for commodities to sustain our daily life including pigments, plastic stabilizers, electroplating, alloys, nickel-Cd batteries and a number of other applications. In spite of unavoidable exploitation of $\mathrm{Cd}$, the metal is very toxic, affecting many cellular functions ${ }^{1-3)}$, and carcinogenic ${ }^{4,5)}$, possibly through stimulation and misregulation of proto-oncogenes ${ }^{3,6,7)}$. Although $\mathrm{Cd}$ is a non-Fenton metal and does not generate free radicals by itself, some $\mathrm{Cd}$ cytotoxity has been shown to be mediated by the production of reactive oxygen species

*To whom correspondence should be addressed.
(ROS) in the presence of metallothioneins (MTs) containing Fenton metals ${ }^{8-10)}$. Cd is also suspected to act as an endocrine disrupter at very low concentrations since it has various effects on estrogen receptor ${ }^{11-13)}$. Accordingly, this metal is still one of the real problems in industrial hygiene ${ }^{1,14-16)}$. However, $\mathrm{Cd}$ is not rare on the earth, rather familiar to terrestrial lives. Therefore, they including human beings have no choice but to develop cellular devices to minimize danger from this metal in order to protect life. MTs ${ }^{17)}$ and heat shock proteins ${ }^{18)}$ (HSPs) are well known to be transcriptionally induced by $\mathrm{Cd}$ and play important protective roles. Despite the accumulation of knowledge of human genes whose expression is increased or decreased by $\mathrm{Cd}$, its biological effects and the mechanisms of its toxicity are not yet well understood. If we could obtain the entire list of human genes whose expression is changed after $\mathrm{Cd}$ exposure, it would provide us with important information not only on mechanisms to protect against $\mathrm{Cd}$ exposure but also on those 
of the toxicity $\mathrm{Cd}$ exerts in human cells. The recently developed DNA microarray technology ${ }^{19,20)}$ allows us to monitor the expression of thousands of genes simultaneously and provides the means of identifying genes whose expression is altered by exposure to toxicants. This paper describes a study in which gene expression changed by $\mathrm{Cd}$ exposure was examined with a microarray containing 7,075 human cDNAs.

\section{Materials and Methods}

\section{Preparation of polyadenylated RNA}

Culture of HeLa S3 cells, Cd exposure and preparation of total RNA were described previously ${ }^{21)}$. Briefly, cells were plated $\left(4 \times 10^{6}\right.$ cells $/ 10 \mathrm{ml}$ medium $/ 100-\mathrm{mm}$ Falcon plastic dish) and incubated for 3 days. Cultures were then incubated with or without $5 \mu \mathrm{M} \mathrm{CdSO}_{4}$ for $6 \mathrm{~h}$ before harvesting. Total cellular RNA was extracted by the acid guanidinium thiocyanate-phenol-chloroform extraction method $^{22)}$. Polyadenylated RNA was isolated from the total RNA with an Oligotex-dT30 < super> mRNA purification kit (Roche). The purity of the polyadenylated RNA was confirmed by the $\mathrm{A}_{260} / \mathrm{A}_{280}$ ratio (>2.05). No degradation of specific mRNA was observed in northern blot analysis employing digoxigenin-labeled probes for human $\beta$-actin and human metallothionein-II A (MT-IIA) ${ }^{21)}$ messages.

\section{DNA microarray analysis}

Microarray analysis was performed by Incyte Genomics Inc. (San Francisco, CA). Briefly, polyadenylated RNA from untreated cells or Cd-treated cells was reverse transcribed in the presence of $\mathrm{Cy} 3$ or Cy5-labeled nucleotides, respectively. These two sets of cDNA probes were hybridized to a UniGEM Human V cDNA microarray containing 7,075 immobilized cDNA fragments. The intensity of $\mathrm{Cy} 3$ and Cy5 fluorescence at a given spot on the microarray was used to quantify the differential expression of the corresponding gene.

\section{Survey of upstream regulatory sequences}

We performed a search for an enhancer sequence termed metal responsive element (MRE) ${ }^{23,24)}$, which contains a conserved core sequence TGCRCNC ( $\mathrm{R}=$ purine; $\mathrm{N}=$ any base), in the upstream region of every gene listed in Table 1. The sequence of a given cDNA was used as a bait to find a full-length mRNA in the database of the National Center for Biotechnology Information (NCBI) by means of the Basic Local Alignment Search Tool (BLAST) program. The fulllength mRNA was then employed as a secondary bait to approach a genome sequence in the high throughput genome sequence (htgs) database of NCBI. The sequence more than $1 \mathrm{~kb}$ from the transcription start site was examined as to whether putative MREs were present or not. There were some cases in which we failed to determine the start site or obtain an upstream sequence longer than $1 \mathrm{~kb}$. These are indicated as n.d. (for "not determined") in Table 1.

\section{Results and Discussions}

To obtain an insight into the biological effects of $\mathrm{Cd}$ and to understand the cellular protection mechanism against it, we used microarray analysis to identify genes whose expression is changed upon treatment of HeLa cells with 5 $\mu \mathrm{M} \mathrm{CdSO}_{4}$. Out of 7,075 human cDNAs examined, the expression was increased for 46 genes (Table 1) and was decreased for 10 genes (Table 2) twofold or greater.

\section{Induction of stress response gene expression}

The genes mentioned hereafter are correlated to Table 1 by indicating the gene numbers (shown in the lefthand column in Table 1) in brackets. Genes classified into the stress response genes and those relevant to gene regulation are indicated by circles in the "Stress response" and "Gene regulation" columns in Table 1, respectively.

MTs are low molecular weight cysteine-rich proteins which are known to be metal-inducible and to play a major role in heavy metal detoxification. MTs sequester heavy metals by chelating them ${ }^{17)}$. As expected from our previous data on Cd-induced MT gene expression in human cells ${ }^{16,21,25)}$, MT genes were highly inducible [1, 5, 6 and 9]. However, in man, MT genes comprise a multigene family classified into four isoform gene groups (MT-I, -II, -III and $-I V$ ). Induction of the MT-IL [1] and MT-III genes [9] in HeLa cells is unlikely since the $M T-I L$ gene is not transcribed ${ }^{26)}$ and MT-III is found only in brain ${ }^{27,28)}$. The signals for $M T$ $I L$ and MT-III might probably reflect hybridization with other functional MT isoform mRNAs (for example, MT IIA ${ }^{29)}$ which is approximately $90 \%$ homologous to $M T-I L$ and $M T$ III in nucleotide sequence). The apparent induction ratio of MT-IL is comparable to that of MT-IIA obtained by northern blot analysis ${ }^{21}$. This case warns us to be prudent in interpreting the data from DNA arrays.

HSPs represent a major group of stress response proteins ${ }^{18)}$. Many of them including HSP110, HSP90, HSP70, HSP60 and HSP32 have been shown to be Cd-inducible ${ }^{3,21,30 \text {. }}$. Consistent with this, transcription of the $h s p 70$ isoform genes $^{31)}$ was highly inducible by Cd: hsp70-1 [2], hsp 70-6 [3], hsp70-5 [4]. Their roles as chaperons might be important 
Table 1. Cd-induced gene expression detected by DNA microarray analysis

\begin{tabular}{|c|c|c|c|c|c|}
\hline No & $\begin{array}{l}\text { Induction } \\
\text { (fold) }\end{array}$ & Gene Product & $\begin{array}{c}\text { Stress } \\
\text { response }\end{array}$ & $\begin{array}{c}\text { Gene } \\
\text { regulation }\end{array}$ & $\begin{array}{c}\text { MRE core } \\
\text { within }-1 \mathrm{~kb}\end{array}$ \\
\hline 1 & 58.8 & MTI-IL* & & & 5 \\
\hline 2 & 11.6 & HSP70-1 & $\bigcirc$ & & 0 \\
\hline 3 & 7.7 & HSP70-6 (HSP70B') & $\bigcirc$ & & 0 \\
\hline 4 & 7.1 & HSP70-5 (GRP78) & $\bigcirc$ & & 0 \\
\hline 5 & 6.5 & MT-IE & $\bigcirc$ & & 4 \\
\hline 6 & 5.3 & MT-IB** & $\bigcirc$ & & 4 \\
\hline 7 & 4.4 & spermine/spermidine acetyltransferase & $\bigcirc$ & & 0 \\
\hline 8 & 4.4 & HSP110 $\alpha$ & $\bigcirc$ & & n.d. \\
\hline 9 & 3.8 & MT-III & & & 7 \\
\hline 10 & 3.4 & ferritin, heavy polypeptide 1 & $\bigcirc$ & & 3 \\
\hline 11 & 3.3 & arginine-rich protein & & & 0 \\
\hline 12 & 3.3 & human hbc647 mRNA sequence & & & n.d. \\
\hline 13 & 2.9 & interleukin 7 (IL-7) receptor & $\bigcirc$ & $\bigcirc$ & n.d. \\
\hline 14 & 2.9 & spinocerebellar ataxia 2 & & & n.d. \\
\hline 15 & 2.8 & HSP40 (HDJ-1) & $\bigcirc$ & & n.d. \\
\hline 16 & 2.7 & EST & & & n.d. \\
\hline 17 & 2.6 & soluble methyl glutaryl CoA synthase & & & 1 \\
\hline 18 & 2.5 & keratin 17 & & & 2 \\
\hline 19 & 2.5 & Mn superoxide dismutase (Mn SOD) & O & & n.d. \\
\hline 20 & 2.5 & mafG & & $\bigcirc$ & n.d. \\
\hline 21 & 2.4 & retinoid X receptor $\gamma(\mathrm{RXR} \gamma)$ & & O & n.d. \\
\hline 22 & 2.4 & HSP70/HSP90-organizing protein (Hop) & O & & 0 \\
\hline 23 & 2.3 & amino acid transporter system A1 (ATA1)*** & & & 4 \\
\hline 24 & 2.3 & bactericidal/permeability-increasing protein & $\bigcirc$ & & 0 \\
\hline 25 & 2.3 & glucan (1,4-alpha-), branching enzyme 1 & & & n.d. \\
\hline 26 & 2.2 & ubiquitin $\mathrm{B}$ & & & 1 \\
\hline 27 & 2.2 & EST & & & 1 \\
\hline 28 & 2.2 & malic enzyme 1 , soluble & & & n.d. \\
\hline 29 & 2.2 & Mif1 & $\bigcirc$ & & 1 \\
\hline 30 & 2.1 & EST & & & n.d. \\
\hline 31 & 2.1 & interleukin 1 , alpha (IL-1 $\alpha)$ & O & $\bigcirc$ & 1 \\
\hline 32 & 2.1 & ferritin, light polypeptide & $\bigcirc$ & & n.d. \\
\hline 33 & 2.1 & H.sapiens polyA site DNA & & & n.d. \\
\hline 34 & 2.1 & cytokine inducible nuclear protein, $\mathrm{C} 193$ & & & n.d. \\
\hline 35 & 2.1 & neuronal precursor cell-expressed developmentally down-regulated (Nedd4) & & & 2 \\
\hline 36 & 2.1 & lysine hydroxylase 2 & & & 2 \\
\hline 37 & 2.1 & calcyclin binding protein & & & n.d. \\
\hline 38 & 2.1 & annexin I (lipocortin I) & $\bigcirc$ & & 0 \\
\hline 39 & 2.0 & $\mathrm{v}$-abelson murine leukemia oncogene (V-abl) homolog 2 product & O & O & 1 \\
\hline 40 & 2.0 & EST & & & n.d. \\
\hline 41 & 2.0 & $\gamma$-glutamylcysteine synthetase, catalytic ( $\gamma \mathrm{GCS})$ & $\bigcirc$ & & 2 \\
\hline 42 & 2.0 & importin (karyopherin) $\beta 2$ & & $\bigcirc$ & n.d. \\
\hline 43 & 2.0 & HSP90 $\beta$ & $\bigcirc$ & & 1 \\
\hline 44 & 2.0 & retinoic acid induced 3 & & & n.d. \\
\hline 45 & 2.0 & reduced in tumor 42kd (rit42, RTP, Ndr1, Cap43, TDD5, Drg1) & $\bigcirc$ & & n.d. \\
\hline 46 & 2.0 & HSP60-1 (chaperonin) & $\bigcirc$ & & 6 \\
\hline
\end{tabular}

Clones showing $>98 \%$ identity over 300 nucleotides were assumed to be identical to known sequences, if not otherwise indicated. *shows $87 \%$ identity of 296 nucleotides to MT1L. ** shows $87 \%$ identity of 239 nucleotides to MT1B. ***shows $95 \%$ identity of 600 nucleotides to ATA1. n.d., "not determined"; MT, metallothionein; HSP, heat shock protein; EST, expressed sequence tag. 
Table 2. Cd-repressed gene expression detected by DNA microarray analysis

\begin{tabular}{lcl}
\hline No & Repression (fold) & \multicolumn{1}{c}{ Gene Product } \\
\hline 1 & 2.9 & natural killer group 2D (NKG2D) \\
2 & 2.7 & methionine adenosyltransferase II, alpha (MAT II $\alpha)^{*}$ \\
3 & 2.4 & hypothetical protein MGC2217 \\
4 & 2.4 & never in mitosis gene a (NIMA)-related kinase 3 \\
5 & 2.4 & dermatan sulphate proteoglycan 3** \\
6 & 2.2 & cerebellar degeneration-related protein (34kD) \\
7 & 2.1 & regulatory factor X, 5 \\
8 & 2.1 & KIAA0535 gene product \\
9 & 2.1 & one twenty-two (OTT) \\
10 & 2.1 & high mobility group protein isoform I-C (HMGIC) \\
\hline
\end{tabular}

Clones showing $>98 \%$ identity over 400 nucleotides were assumded to be identical to known sequences, if not otherwise indicated. *shows $100 \%$ identity of 273 nucleotides to MAT. **shows $96 \%$ identity of 475 nucleotides to dermatan sulphate proteoglycan 3 . n.d., "not determined".

to renature cellular proteins impaired by $\mathrm{Cd}^{18,32,33)}$. The level of $h s p 70-1$ induction [2] was consistent with the results of northern blot analysis ${ }^{21}$. In addition to this, many other $h s p$ genes (hsp 110 [8], hsp40 [15], hsp90 [43], hsp60 [46]) and an $h s p$-related gene (Hop [22]) were induced, which are expected to be relevant to protein renaturation and gene regulation, etc.

\section{Responses possibly mediated by oxidative stress}

Since $\mathrm{Cd}$ is not one of the Fenton metals, Cd itself is not redox active and does not generate free radicals ${ }^{8,9)}$. But it has been shown that $\mathrm{Cd}$ produces hydroxyl radicals by displacing protein-bound Fenton metals $(\mathrm{Fe}$ or $\mathrm{Cu}$, for example $)^{9)}$. Accordingly $\mathrm{Cd}$ can cause oxidative stress and lipid peroxidation as if it were redox active. Among the stress response genes indicated in Table 1, there are several antioxidant genes such as spermine/spermidine acetyl transferase $^{34)}$ [7], heavy ${ }^{35)}$ [10] and light [32] polypeptides ${ }^{36)}$ of ferritin, Mn superoxide dismutase (SOD) ${ }^{37)}[19]$ and $\gamma$ glutamylcysteine synthetase $(\gamma \mathrm{GCS})^{38)}[41]$ which synthesizes glutathione. The amino acid transporter system A1 (ATAl) gene [23] was also induced, which transports short-chain neutral amino acids including methionine, serine and glutamine ${ }^{39)}$ into cells. These amino acids are easily converted into one another, and their positions in the metabolic map are very close to glutathione (GSH). Cellular demands for these amino acids would be increased in Cd-exposed cells since cysteine and methionine residues are particularly vulnerable to $\operatorname{ROS}^{40)}$. Malic enzyme ${ }^{41)}$ [28] catalyzes production of NADH which would help to reduce oxidized substances.

In addition, several Cd-induced changes also appear to be relevant to the damage caused by ROS. Soluble methylglutaryl-CoA synthase ${ }^{42)}$ [17] supplies starting substrates for the synthesis of sterols and fatty acids essential for cell membrane, which is impaired by lipid peroxidation caused by ROS. ROS not only modifies amino acid residues but also attacks the backbones of proteins ${ }^{40}$. Breakage of peptide bonds can no longer be renatured by chaperons ${ }^{18)}$, and the final remedy of the proteins might be degradation of themselves. It has been reported that S. cervisiae strains lacking ubiquitin (Ub)-dependent proteolysis is sensitive to $\mathrm{Cd}^{43)}$, suggesting that the elimination of the damaged proteins is important to circumvent $\mathrm{Cd}$ toxicity. In HeLa cells major ubiquitins, $\mathrm{UbB}$ [26] and $\mathrm{UbC}^{44)}$ (1.9 fold induced; not shown in Table 1), and one of Ub-protein ligase, Nedd4 (neuronal precursor cell-expressed developmentally down-regulated $4)^{45)}[35]$ are induced by Cd. It appears likely that a similar mechanism works in human cells.

\section{Induction of other genes by Cadmium}

Epression of rit42 (reduced in tumor 42kd) gene [45] (also named RTP/Drg 1/Cap43/TDD5/Ndrl $)^{46)}$ was increased twofold. It has been reported that rit 42 mRNA is expressed in a cell-cycle dependent manner: high levels in the $G_{1}$ and $\mathrm{G}_{2}-\mathrm{M}$ phases and low levels in the $\mathrm{S}$ phase ${ }^{47}$. In addition, many tumor cells do not express rit42 and its overexpression decreases cell proliferation. These facts suggest that the induction of rit42 gene by $\mathrm{Cd}$ would result in growth inhibition which is probably advantageous to cells in recovering from damage.

The "Gene regulation" column of Table 1 indicates genes whose products are known to affect the expression of other genes. These include interleukin 7 (IL7) receptor ${ }^{48)}$ [13], 
interleukin 1 (IL1 ${ }^{49)}[31]$ and $\mathrm{C} 193^{50)}$ [34] and $m a f G^{51)}$ [20] and retinoid X receptor (RXR) $\gamma^{52)}$ [21]. Abelson murine leukemia oncogene $(\mathrm{V}-\mathrm{abl})$ encodes a protein tyrosine kinase. It is known to be negatively regulated by retinoblastoma protein and positively regulated by DNA damage signals, and is assumed to affect the expression of other genes ${ }^{53)}$ although little is known about its target genes. The $v$-abl homolog 2 [39] gene product is expected to have a similar activity. Importin [42] supports the nuclear transport of many proteins containing histones, ribosomal proteins, p53 and heat shock transcription factors ${ }^{54)}$. Cd-induced changes in the expression of the above-mentioned genes are expected to influence a number of cellular functions, many of which may probably be involved in the protective mechanisms.

\section{Upstream MRE of the listed genes}

Heavy metal-dependent induction of mammalian MT genes is mediated by repeats of the MRE enhancer sequence, which contains a conserved core sequence TGCRCNC and a less conserved GC-rich region. The core sequence has been reported to be essential for mediating metal response ${ }^{23,24)}$. Out of the genes listed in Table 1, 14 genes other than those coding for MTs were found to have the MRE consensus sequence within $1 \mathrm{~kb}$ of their upstream region. These genes include the gene encoding $\gamma G C S$ which is known to be controlled by MRE and MRE-binding transcription factor 1 (MTF-1 $)^{38)}$. Also some additional genes might actually have functional MREs. Since certain MRE sequences are known to be inactive ${ }^{55)}$, an MRE-like sequence should be carefully inspected to see whether it is truly functional or not before conclusion.

In the present work, we examined changes in the gene expression profile of HeLa cells after exposure to $5 \mu \mathrm{M}$ $\mathrm{CdSO}_{4}$ for $6 \mathrm{~h}$. This non-lethal condition ${ }^{10,16)}$ was chosen to see mainly cellular protective responses, rather than the results of metal toxicity. In summary, the cells appear to use all their genomic resources to overcome the burden as follows. MTs are induced to sequester the metal by chelating. HSPs function as chaperons to renature cellular proteins. Metabolism inclines toward synthesis of cysteine and glutathione. Anti-oxidant genes and some other genes are also induced to quench ROS and to repair cell components, respectively. A great many cellular functions are controlled by induced regulatory genes. The Ub pathway is activated to degrade some proteins which cannot be renatured.

The array used in this study contained 7,075 genes randomly selected from the human cDNA library. Since the total number of human genes is estimated to be about
$30,000^{56)}$ to $50,000^{57)}, 4$ to 7 times more genes than those we inspected remain to be examined. Moreover, detection of Cd-induced changes in gene expression was limited since dose- and time-dependent changes could not be addressed by the present analysis. Higher concentrations of $\mathrm{Cd}$, for example, would give much different expression profiles, probably reflecting to a greater extent the expression of cytotoxicity. Further studies are required to see the entire image of Cd effects.

As documented above with an example of $\mathrm{Cd}$ exposure, microarray analysis is a powerful tool for studying toxicantinduced gene expression profiles. Analysis of altered gene expression after exposure to industrial hazardous factors would contribute much to understanding the mechanisms of toxicity and protection against it, and also to practical aspects in occupational health such as providing indices for biological effects of the hazardous factors and human sensitivity to them.

\section{References}

1) W.H.O. (1992) Environmental health criteria 134: Cadmium, 1st Ed., World Health Organization, Geneva, Switzerland.

2) Vido K, Spector D, Lagniel G, Lopez S, Toledano MB, Labarre J (2001) A proteome analysis of the cadmium response in Saccharomyces cerevisiae. J Biol Chem 276, 8469-74.

3) Beyersmann D, Hechtenberg $S$ (1997) Cadmium, gene regulation, and cellular signaling in mammalian cells. Toxicol Appl Pharmacol 144, 247-61.

4) Hart BA, Potts RJ, Watkin RD (2001) Cadmium adaptation in lung-a double-edged sword? Toxicol 160, 65-70.

5) Waalkes MP (2000) Cadmium carcinogenesis in review. $\mathrm{J}$ Inorg Biochem 79, 241-4.

6) Jin P, Ringertz NR (1990) Cadmium induces transcription of proto-oncogenes c-jun and c-myc in rat L6 myoblasts. J Biol Chem 265, 14061-4.

7) Wang Z, Templeton DM (1998) Induction of c-fos protooncogene in mesangial cells by cadmium. J Biol Chem 273, 73-9.

8) Thévenod F, Friedmann JM, Katsen AD, Hauser LA (2000) Up-regulation of multidrug resistance pglycoprotein via nuclear factor- $\kappa \mathrm{B}$ activation protects kidney proximal tubule cells from cadmium- and reactive oxygen species-induced apoptosis. J Biol Chem 275, 1887-96.

9) O'Brien P, Salacinski HJ (1998) Evidence that the 
reactions of cadmium in the presence of metallothionein can produce hydroxyl radicals. Arch Toxicol 72, 690700.

10) Szuster-Ciesielska A, Stachura A, Slotwinska M, Kaminska T, Sniezko R. Paduch R, Abramczyk D, Filar J, Kandefer-Szerzen M (2000) The inhibotory effect of zinc on cadmium-induced cell apoptosis and reactive oxygen species (ROS) production in cell cultures. Toxicology 145, 159-71.

11) Stoica A, Katzenellenbogen BS, Martin MB (2000) Activation of estrogen receptor-alpha by the heavy metal cadmium. Mol Endocrinol 14, 545-53.

12) Garcia-Morales P, Saceda M, Kenney N, Kim N, Salomon DS, Gottardis MM, Solomon HB, Sholler PF, Jordan VC, Martin MB (1994) Effect of cadmium on estrogen receptor levels and estrogen-induced responses in human breast cancer cells. J Biol Chem 269, 16896-901.

13) Guével RL, Petit FG, Goff PL, Métivier R, Valotaire Y, Pakdel F (2000) Inhibition of rainbow trout estrogen receptor activity by cadmium. Biol Reproduct 63, 25966.

14) Kjellström $T$ (1979) Exposure and accumulation of cadmium in populations from Japan, the United States, and Sweden. Environ Health Perspect 28, 169-97.

15) McDiarmid MA, Freeman CS, Grossman EA, Martnik J (1996) Biological monitoring results for cadmiumn exposed workers. AIHA J 57, 1019-23.

16) Yamada H, Kiozumi S (2001) Lymphocyte matallothionein-mRNA as a sensitive biomarker of cadmium exposure. Ind Health 39, 29-32.

17) Klaassen CD (Ed.) (1999) Metallothionein IV. Birkhäuser Verlag, Basel.

18) Morimoto RI, Tissières A, Georgopoulos C (Eds.) (1990) Stress proteins in biology and medicine. Cold Spring Harbor Laboratory Press.

19) Schena M, Shalon D, Davis RW, Brown PO (1995) Quantitative monitoring of gene expression patterns with a complementary DNA microarray. Science 270, 467-70.

20) Maxwell SA, Davis GE (2000) Differential gene expression in p53-mediated apoptosis-resistant vs. apoptosis-sensitive tumor cell lines. Proc Natl Acad Sci USA 97, 13009-14.

21) Murata M, Gong P, Suzuki K, Koizumi S (1999) Differential metal response and regulation of human heavy metal inducible genes. J Cell Physiol 180, 10513.

22) Chomezynski P, Sacchi N (1987) Single-step method of RNA isolation by acid guanidinium thiocyanate- phenol-chloroform extraction Anal Biochem 162, 1569.

23) Stuart GW, Searle PF, Palmiter RD (1985) Identification of multiple metal regulatory elements in mouse metallothionein-I promoter by assaying synthetic sequences. Nature 317, 828-31.

24) Culotta VC, Hamer DH (1989) Fine mapping of a mouse metallothionein gene metal response element. Mol Cell Biol 9, 1376-80.

25) Kiozumi S, Sone T, Otaki N, Kimura M (1985) Cdinduced synthesis of metallothionein in HeLa cells. Biochem J 227, 879-86.

26) Stennard FA, Holloway AF, Hamilton J, West AK (1994) Characterization of six additional human metallothionein genes. Biochim Biophys Acta 1218, $357-65$

27) Tsuji S, Kobayashi H, Uchida Y, Ihara Y, Miyatake T (1992) Molecular cloning of human growth inhitory factor cDNA and its down regulation in Alzheimer's disease. EMBO J 11, 4843-50.

28) Palmiter RD, Findley SD, Whitmore TE, Durnam DM (1992) MT-III, a brain-specific member of the metallothionein gene family. Proc Natl Acad Sci USA 89, 6333-7.

29) Karin M, Richard RI (1982) Human metallothionein genes-primary structure of the metallothionein-II gene and a related processed gene. Nature 299, 797-802.

30) Goering PL, Fisher B, Kish CL (1993) stress protein synthesis induced in rat liver by cadmium precedes hepatotoxicity. Toxicol Appl Pharmacol 122, 139-48.

31) Tavaria M, Gabriele T, Kola I, Anderson RL (1996) A hitchhiker's guide to the human Hsp70 family. Cell Stress Chaperons 1, 23-81.

32) Liao V H-C, Freedmann JH (1998) Cadmium-regulated genes from the nematode C. elegans, Identification and cloning of new cadmium-responsive genes by differential display. J Biol Chem 273, 31962-70.

33) Wickner S, Maurizi MR, Gottesman S (1999) Posttranslational quality control: folding, refolding, and degrading proteins. Science 286, 1888-93.

34) Xiao L, Casero RA (1996) Differential transcription of the human spermidine/spermine $N^{1}$-acetyltransferase (SSAT) gene in human lung carcinoma cells. Biochem J 313, 691-6.

35) Tsuji Y, Ayaki H, Whitman SP, Morrow CS, Torti SV, Torti FM (2000) Coordinate transcriptional and translational regulation of ferritin in response to oxidative stress. Mol Cell Biol 20, 5818-27.

36) Jang MK, Choi M, Park YB (1999) Regulation of ferritin 
light chain gene expression by oxidized low-density lipoproteins in human monocytic THP-1 cells. Biochem Biophys Res Commun 265, 577-83.

37) Melov S, Coskun P, Patel M, Tuinstra R, Cottrell B, Jun AS, Zastawny TH, Dizdaroglu M, Goodman S, Huang T, Miziorko H, Epstein CJ, Wallace DC (1999) Mitochondrial disease in superoxide dismutase 2 mutant mice. Proc Natl Acad Sci USA 96, 846-51.

38) Günes Ç, Heuchel R, Georgiev O, Muller KH, Lichtlen P, Bluthmann H, Marino S, Aguzzi A, Schaffner W (1998) Embryonic lethality and liver degeneration in mice lacking the metal-responsive transcription activator MTF-1. EMBO J 17, 2846-54.

39) Wang H, Huang W, Sugawara M, Devoe LD, Leibach FH, Prasad PD, Ganapathy V (2000) Cloning and functional expression of ATA1, a subtype of amino acid transporter A, from human placenta. Biochem Biophys Res Commun 273, 1175-9.

40) Berlett BS, Stadtman ER (1997) Protein oxidation in aging, disease, and oxidative stress. J Biol Chem 272, 20313-6.

41) Yang Z, Batra R, Floyd DL, Hung H, Chang G, Tong L (2000) Potent and competititve inhibition of malic enzymes by lanthanide ions. Biochem Biophys Res Commun 274, 440-4.

42) Hegardt FG (1999) Mitochondrial 3-hydroxyl-3methylglutaryl-CoA synthetase: a control enzyme in ketogenesis. Biochem J 338, 569-82.

43) Jungmann J, Reins H, Schobert C, Jentsch S (1993) Resistance to cadmium mediated by ubiquitindependent proteolysis. Nature 361, 396-71.

44) Fornace AJ, Alamo I, Hollander MC, Lamoreaux E (1989) Ubiquitin mRNA is a major stress-induced transcript in mammalian cells. Nucleic Acids Res 17, 1215-30.

45) Hamilton MH, Tcherepanova I, Huibregtse M, McDonnell DP (2001) Nuclear import/export of hRPF1/ Nedd4 regulates the ubiquitin-dependent degradation of its nuclear substrates. J Biol Chem 276, 26324-31.

46) Agarwala KL, Kokame K, Kato H, Miyata T (2000) Phosphorylation of RTP, an ER stress-responsive cytoplasmic protein. Biochem Biophys Res Commun 272, 641-7.

47) Kurdistani SK, Arizti P, Reimer CL, Sugrue MM, Aaronson SA, Lee SW (1998) Inhibition of tumor cell growth by RTR/rit42 and its responsiveness to 553 and DNA damage. Cancer Res 58, 4439-44.

48) Hofmeister R, Khaled AR, Benbernou N, Rajnavolgyi E, Muegge K, Durum SK (1999) Interleukin-7: physiological roles and mechanisms of action. Cytokinine Growth Factor Rev 10, 41-60.

49) Gubler I, Chua AO, Stern AS, Hellmann CP, Vitek MP, Dechiara TM, Benjamin WR, Collier KJ, Dukovich M, Familletti PC, Fiedler-Nagy C, Jenson J, Kaffka K, Kilian PL, Stremlo D, Wittreich BH, Woehle D, Mizel SB, Lomedico PT (1986) Recombinant human interleukin $1 \alpha$ : purification and biological characterization. J Immunol 136, 2492-7.

50) Chu W, Burns DK, Swerlick RA, Presky DH (1995) Identification and characterization of a novel cytokineinducible nuclear protein from human endothelial cells. J Biol Chem 270, 10236-45.

51) Suzuki T, Blank V, Sesay JS, Crawford DR (2001) Maf genes are involved in multiple stress response in human. Biochem Biophys Res Commun 280, 4-8.

52) Casaar-Malek I, Marchal S, Rochard P, Casas F, Wrutniak C, Samarut J, Cabello G (1996) Induction of c-Erb AAP-1 interactions and c-Erb A transcriptional activity in myoblasts by RXR. J Biol Chem 271, 11392-9.

53) Wang JY (2000) Regulation of cell death by the abl tyrosine kinase. Oncogene 19, 5643-50.

54) Bonifaci N, Moroianu J, Radu A, Blobel G (1997) Karyopferin $\beta 2$ mediates nuclear import of a mRNA binding protein. Proc Natl Acad Sci USA 94, 5055-60.

55) Koizumi S, Suzuki K, Ogra Y, Yamada H, Otsuka F (1999) Transcriptionalactivity and regulatory protein binding of metal-responsive elements of human metallothioneinIIA gene. Eur J Biochem 259, 635-42.

56) Venter JC, Adams MD, Myers EW, Li PW, Mural RJ, Sutton GG, Smith HO, Yandell M, Evans CA, Holt RA, Gocayne JD, Amanatides P, Ballew RM, Huson DH, Wortman JR, Zhang Q, Kodira CD, Zheng XH, Chen L, Skupski M, Subramanian G, Thomas PD, Zhang J, Gabor Miklos GL, Nelson C, Broder S, Clark AG, Nadeau J, McKusick VA, Zinder N, Levine AJ, Roberts RJ, Simon M, Slayman C, Hunkapiller M, Bolanos R, Delcher A, Dew I, Fasulo D, Flanigan M, Florea L, Halpern A, Hannenhalli S, Kravitz S, Levy S, Mobarry C, Reinert K, Remington K, Abu-Threideh J, Beasley E, Biddick K, Bonazzi V, Brandon R, Cargill M, Chandramouliswaran I, Charlab R, Chaturvedi K, Deng Z, Di Francesco V, Dunn P, Eilbeck K, Evangelista C, Gabrielian AE, Gan W, Ge W, Gong F, Gu Z, Guan P, Heiman TJ, Higgins ME, Ji RR, Ke Z, Ketchum KA, Lai Z, Lei Y, Li Z, Li J, Liang Y, Lin X, Lu F, Merkulov GV, Milshina N, Moore HM, Naik AK, Narayan VA, Neelam B, Nusskern D, Rusch DB, Salzberg S, Shao W, Shue B, Sun J, Wang Z, Wang A, Wang X, Wang J, 
Wei M, Wides R, X Zhong W, Zhu S, Zhao S, Gilbert D, Baumhueter S, Spier G, Carter C, Cravchik A, Woodage T, Ali F, An H, Awe A, Baldwin D, Baden H, Barnstead M, Barrow I, Beeson K, Busam D, Carver A, Center A, Cheng ML, Curry L, Danaher S, Davenport L, Desilets R, Dietz S, Dodson K, Doup L, Ferriera S, Garg N, Gluecksmann A, Hart B, Haynes J, Haynes C, Heiner C, Hladun S, Hostin D, Houck J, Howland T, Ibegwam C, Johnson J, Kalush F, Kline L, Koduru S, Love A, Mann F, May D, McCawley S, McIntosh T, McMullen I, Moy M, Moy L, Murphy B, Nelson K, Pfannkoch C, Pratts E, Puri V, Qureshi H, Reardon M, Rodriguez R, Rogers YH, Romblad D, Ruhfel B, Scott R, Sitter C, Smallwood M, Stewart E, Strong R, Suh E, Thomas R, Tint NN, Tse S, Vech C, Wang G, Wetter J, Williams S, Williams M, Windsor S, Winn-Deen E, Wolfe K, Zaveri J, Zaveri K, Abril JF, Guigo R, Campbell MJ, Sjolander KV, Karlak B, Kejariwal A, Mi H, Lazareva B, Hatton T, Narechania A, Diemer K, Muruganujan A, Guo N, Sato S, Bafna V, Istrail S,
Lippert R, Schwartz R, Walenz B, Yooseph S, Allen D, Basu A, Baxendale J, Blick L, Caminha M, CarnesStine J, Caulk P, Chiang YH, Coyne M, Dahlke C, Mays A, Dombroski M, Donnelly M, Ely D, Esparham S, Fosler C, Gire H, Glanowski S, Glasser K, Glodek A, Gorokhov M, Graham K, Gropman B, Harris M, Heil J, Henderson S, Hoover J, Jennings D, Jordan C, Jordan J, Kasha J, Kagan L, Kraft C, Levitsky A, Lewis M, Liu X, Lopez J, Ma D, Majoros W, McDaniel J, Murphy S, Newman M, Nguyen T, Nguyen N, Nodell M, Pan S, Peck J, Peterson M, Rowe W, Sanders R, Scott J, Simpson M, Smith T, Sprague A, Stockwell T, Turner $\mathrm{R}$, Venter E, Wang M, Wen M, Wu D, Wu M, Xia A, Zandieh A, Zhu X (2001) The sequence of the human genome. Science 291, 1304-51.

57) Hogenesch JB, Ching KA, Batalov S, Su AI, Walker JR, Zhou Y, Kay SA, Schultz PG, Cooke MP (2001) A comparison of the Celera and Ensembl predicted gene sets reveals little overlap in novel genes. Cell 106, 4135 . 